\title{
SEISMIC REFRACTION AND REFLECTION MEASUREMENTS AT “BYRD” STATION, ANTARCTICA*
}

\author{
By Heinz Kohnen and Charles R. Bentley \\ (Geophysical and Polar Research Center, Department of Geology and Geophysics, University \\ of Wisconsin, Middleton, Wisconsin 53562, U.S.A.)
}

\begin{abstract}
Seismic refraction and reflection shooting was carried out along three profiles about $\mathrm{Io} \mathrm{km}$ long, angled $60^{\circ}$ to one another, near "Byrd" station, Antarctica, during the $1970-7$ I field season. No dependence of velocity upon azimuth was found, but velocities at 200 or $300 \mathrm{~m}$ depth were slightly greater than at a site $30 \mathrm{~km}$ away where measurements were made in $195^{8}$. The difference can probably be attributed to different ice fabrics arising from a $50 \%$ difference in snow accumulation rates at the two sites. The velocitydepth and density-velocity functions at the two sites are also significantly different, but close agreement was found at each site between the depths to significant changes in the velocity gradient and the depths of fundamental change in the densification process. Such agreement may permit density-depth curves, and consequently accumulation rates, to be measured by seismic refraction shooting alone.

The reflection shooting on a common reflection-point profile led to a good determination of mean velocity through the ice as a function of angle of incidence. The results agree closely with similar measurements at the 1958 site, and with an anisotropic model based on glaciological and sonic logging observations in the deep drill hole. The mean vertical velocity of $3.90-3.93 \mathrm{~km} / \mathrm{s}$ through the solid ice is about $2 \%$ higher than has commonly been used for determinations of ice thickness from seismic reflection shooting.
\end{abstract}

RÉsumé. Mesures par réfraction et réflexion sismiques à la station "Byrd" en Antarctique. Des tirs pour mesures sismiques par réfraction et réflexion ont été pratiqués le long de trois profils d'environ $10 \mathrm{~km}$ de long faisont un angle de $60^{\circ}$ l'un avec l'autre, près de la station de "Byrd" dans l'Antarctique, pendant la campagne 1970-71. On n'a pas trouvé de relation entre la vitesse et l'orientation, mais les vitesses à 200 ou $300 \mathrm{~m}$ de profondeur étaient légèrement plus grandes qu'en un site distant de $30 \mathrm{~km}$ où des mesures avaient été faites en 1958. La différence peut probablement être attribuée à une différence dans la formation de la glace résultant d'une différence de $50 \%$ dans les vitesses d'accumulation de la neige dans les deux sites. Les fonctions vitesse-profondeur et densité-vitesse aux deux endroits sont significativement différentes, mais une bonne correspondance a été trouvée dans les deux sites entre les profondeurs où se produisent des changements significatifs du gradient de vitesse, et les profondeurs où il y a changement fondamental dans les processus de densification. Une telle correspondance peut permettre de mesurer par la seule méthode des tirs sismiques à la réfraction, les courbes densité-profondeur, et, par conséquent, la vitesse d'accumulation.

Les tirs à la réflexion sur un profil commun de point de réflexion, conduisent à une bonne détermination de la vitesse moyenne à travers la glace, en fonction de l'angle d'incidence. Les résultats concordent bien avec des mesures similaires sur le site de 1958, et avec un modèle anisotropique basé sur des observations glaciologiques et par sondages ioniques dans un forage profond. La vitesse moyenne verticale de 3,90 à $3,93 \mathrm{~km} / \mathrm{s}$ à travers la glace solide est d'environ $2 \%$ supérieure à celle communément utilisée pour les déterminations d'épaisseur de glace à partir de tirs sismiques à la réflexion.

Zusammenfassung. Refraktions- und reflexionsseismische Messungen an der "Byrd" Station, Antarktis. Während der Sommersaison 1970-71 wurden refraktions- und reflexionsseismische Untersuchungen auf drei Profilen nahe der "Byrd" Station in der Antarktis durchgeführt. Die Profile waren etwa ro km lang und unter $60^{\circ} \mathrm{zu}$ einander orientiert. Die seismischen Geswindigkeiten zeigten keine Abhängigkeit vom Azimuth, waren jedoch in $200-300 \mathrm{~m}$ Tiefe geringfügig höher als in entsprechender Tiefe auf einem etwa $30 \mathrm{~km}$ entfernten Profil, wo 1958 seismische Messungen durchgeführt wurden. Dieser Unterschied kann wahrscheinlich auf geringfügige Verschiedenheiten im Kristallgefüge zurückgeführt werden, die möglicherweise durch den Unterschied von $50 \%$ in der Akkumulationsrate an den beiden Stationen verursacht sind. Die Geschwindigkeits-Tiefen- und die Geschwindigkeits-Dichte-Funktionen an beiden Stationen sind ebenfalls signifikant voneinander verschieden. Gute Übereinstimmung wurde jedoch jeweils zwischen den Tiefen markanter Änderungen im Geschwindigkeitsgradienten und den Tiefen bedeutender Änderungen im Verdichtungsvorgang gefunden. Diese Übereinstimmung mag die Bestimmung des Dichte-Tiefenverlaufs und damit der Akkumulationsrate allein aus refraktionsseismischen Messungen erlauben.

Die Reflexionsuntersuchungen auf einem "Common-Reflection-Point"-Profil führten zü einer züverlälligen Bestimmüng der Durchschnittsgeschwindigkeiten im Eis als Funktion des Einfallswinkels. Die Ergebnisse stehen in guter Übereinstimmung mit ähnlichen Messungen an der Station von 1958 und einem Anisotropiemodell, abgeleitet aüs glaziologischen Messungen und dem Sonic Log in der Tief bohrung. Die mittlere Vertikal-Geschwindigkeit von 3,90-3,93 km/s durch das Eis ist ungefähr $2 \%$ höher als die Geschwindigkeiten, die gewöhnlich für die Tiefenberechnungen aus Reflexionsuntersuchungen herangezogen werden.

\section{INTRODUCTION}

Seismic investigations in Antarctica (Bentley, 197I) and on the Greenland ice sheet (Kohnen, unpublished) have shown that the seismic wave velocities in the ice and the firn

\footnotetext{
* Contribution No. 274 of the Geophysical and Polar Research Center, University of Wisconsin.
} 
are affected by anisotropic crystal orientation and by different modes of densification. Wave velocities in the ice have been found to vary by amounts which cannot be explained by different temperatures only but require a varying preferred orientation of the ice crystals. Major changes in the velocity-depth gradient seem to correspond to major changes in the densification rate. To study these effects further, detailed seismic measurements were carried out during the 1970-7I season near new "Byrd" station, Antarctica, where densities and crystal orientations through the ice sheet are known from core studies. The results are presented here together with previously unpublished results of measurements made in 1957 and r 958 near old "Byrd" station, about ro $\mathrm{km}$ to the west.

\section{Field techniques}

The 1970-7I seismic measurements comprised a common-reflection-point profile io $\mathrm{km}$ long (profile I), and two single-ended profiles $10.5 \mathrm{~km}$ (profile 2) and $7.7 \mathrm{~km}$ (profile 3 ) long, angled $60^{\circ}$ to one another. The common central point of the profiles was approximately ro km south-east of new "Byrd" station. The refraction shooting in 1957 and 1958, carried out at a site about ro km north-west of old "Byrd" station, hence about $30 \mathrm{~km}$ north-west of the new "Byrd" site, consisted of two single-ended profiles perpendicular to each other, one (I957) $15 \mathrm{~km}$ and the other (1958) $22 \mathrm{~km}$ long.

An HTL (Texas Instruments) $7000 \mathrm{~B}$ Seismograph System, together with $7 \mathrm{~Hz}$ and $20 \mathrm{~Hz}$ vertical and $7 \mathrm{~Hz}$ horizontal Electro-Tech geophones, was used for all the measurements. The geophone spacing was $30 \mathrm{~m}$ for the more distant shots, closer spacings down to $2 \mathrm{~m}$ being used for shot distances less than a few hundred meters to provide detailed velocity variations in the upper few hundred meters of the ice sheet. Almost all distances, both between geophones and from shot to recording point, were measured with a steel tape. The only exceptions were the shot distances on the 1957 profile, determined by optical range finder. Errors in taped distances, estimated from repeated measurements and from previous experience in Greenland, were less than $0.1 \%$. The uncertainties in range-finder distances were larger, and, since record quality was not high enough for accurate apparent velocity measurements as in 1970-7I (see below), precise determinations of maximum velocities from the 1957 profile were not possible. Timing, checked against radio station WWV, was accurate within $0.03 \%$; corrections ( $\mathrm{I} \mathrm{m} / \mathrm{s}$ maximum) have been applied where they are not completely negligible.

\section{RESULTS OF THE REFRAGTION MEASUREMENTS}

"Maximum" velocities. Seismic refraction profiles on ice sheets mostly yield wave velocities which are very nearly constant at distances greater than a few kilometers, corresponding to a depth of a few hundred meters. Recent analysis of $P$-wave velocities in the deep drill hole at new "Byrd" station, combined with a detailed examination of the $195^{8}$ refraction profile, has shown that in reality the velocity at "Byrd" station continues to increase very slowly with depth, resulting in about a $10 \mathrm{~m} / \mathrm{s}$ increase in the slope of the travel-time curve between 4 and I $2 \mathrm{~km}$ (Bentley, 1972). A true maximum $P$-wave velocity is therefore not attained on the refraction profiles. For comparison between profiles, however, it is sufficient to calculate quasi-maximum velocities by taking the best linear fits to the travel-time curves over similar distance ranges; that is what we have done in this paper, using the distance range $4^{-10} \mathrm{~km}$ $\left(4^{-}-8 \mathrm{~km}\right.$ in the case of profile 3$)$. In the case of $S$-waves, there is no evidence for any appreciable increase in velocity below 200 or $300 \mathrm{~m}$, so a true maximum is probably recorded.

In $1970-71$, difficulty was experienced in properly recording radio-time breaks. Absolute travel times were therefore not available, so maximum $P$ - and $S$-wave velocities, $\left(V_{\mathrm{p}}\right)_{\max }$ and $\left(V_{\mathrm{s}}\right)_{\max }$, were calculated by taking the mean of the apparent velocities across the spread ("cross-spread" velocities; see Figure I). Because $P$-wave travel times can be read very accurately, the standard deviation in $\left(V_{\mathrm{p}}\right)_{\max }$ is about the same from the two methods (Table 
I). $S$-wave arrival times are less accurately determined, however; as a result, there is an order of magnitude difference in the standard deviations for $\left(V_{\mathrm{S}}\right)_{\max }$ between the old "Byrd" and new "Byrd" profiles (Table I).

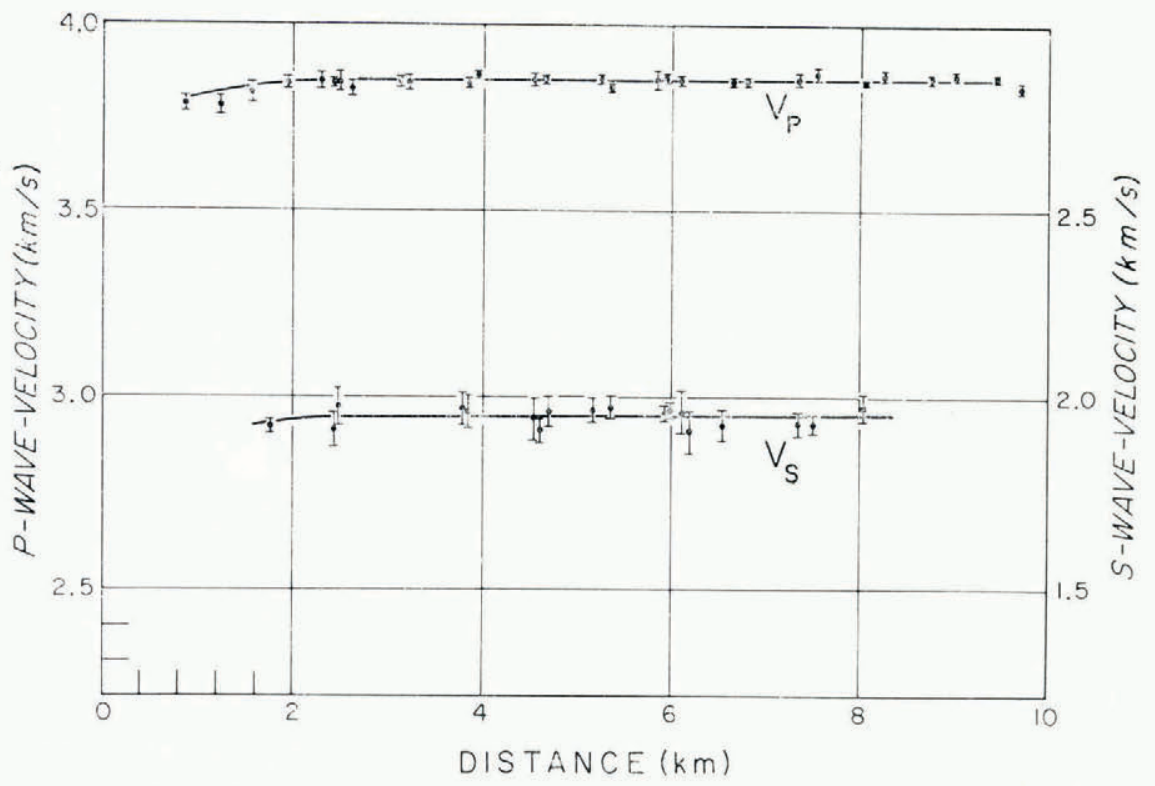

Fig. I. P-wave and $S$-wave cross-spread velocities versus distance, new "Byrd".

Table I. Seismic velocities at new And old "Byrd" STATIONS. FOR OLD "BYRD" $\left(V_{\mathrm{s}}\right)_{\max }$ IS FROM BENTLEY (1971), AND $\left(V_{\mathrm{p}}\right)_{\max }$ FROM DATA IN BENTLEy (1972). $\left(V_{\mathrm{p}}\right)_{\text {max }}$ DIFFERS SLIGHTLY FROM THE REGRESSION LINE FIT IN THE LATTER REFERENCE BECAUSE OF THE LIMITED DISTANCE RANGE USED HERE

$\begin{array}{ccc}\text { Profile } & \left(V_{\mathrm{p}}\right)_{\max } & \left(V_{\mathrm{s}}\right)_{\max } \\ \mathrm{km} / \mathrm{s} & \mathrm{km} / \mathrm{s} \\ \text { New "Byrd", I } & 3.854 \pm 0.003 & 1.949 \pm 0.017 \\ \text { New "Byrd", } 2 & 3.858 \pm 0.004 & 1.949 \pm 0.016 \\ \text { New "Byrd", } 3 & 3.86 \mathrm{1} \pm 0.004 & 1.950 \pm 0.013 \\ \text { Old "Byrd", } & 3.853 \pm 0.004 & 1.934 \pm 0.001\end{array}$

Thus any differences between cross-spread velocities and true velocities which might arise from horizontal inhomogeneity are small compared with the errors of measurement. The velocities at new "Byrd" are higher than those at old "Byrd", however, by $8 \pm 5 \mathrm{~m} / \mathrm{s}$ for $\left(V_{\mathrm{p}}\right)_{\max }$ and ${ }_{15} \pm 9 \mathrm{~m} / \mathrm{s}$ for $\left(V_{\mathrm{s}}\right)_{\max }$. The differences are only marginally significant at the $90 \%$ confidence level, but the fact that both velocities differ lends support to the reality of the result. The most likely cause of small differences would be slightly dissimilar mean fabric patterns. Dissimilar fabrics might well develop even though the sites are only $30 \mathrm{~km}$ apart, since the age of the snow accumulation rate at old "Byrd" is $50 \%$ greater than at new "Byrd" (Gow and Rowland, I965; Gow, I968).

Velocities versus depth. Curves of $V_{\mathrm{p}}$ and $V_{\mathrm{s}}$ versus distance calculated for each of the profiles show no local differences at either of the sites (the three new "Byrd" profiles are shown together in Figure 2). We have therefore calculated mean velocity-depth curves for $P$ - and $S$-waves for each site and plotted them, together with curves of density, $\rho$, versus depth, $z$, 


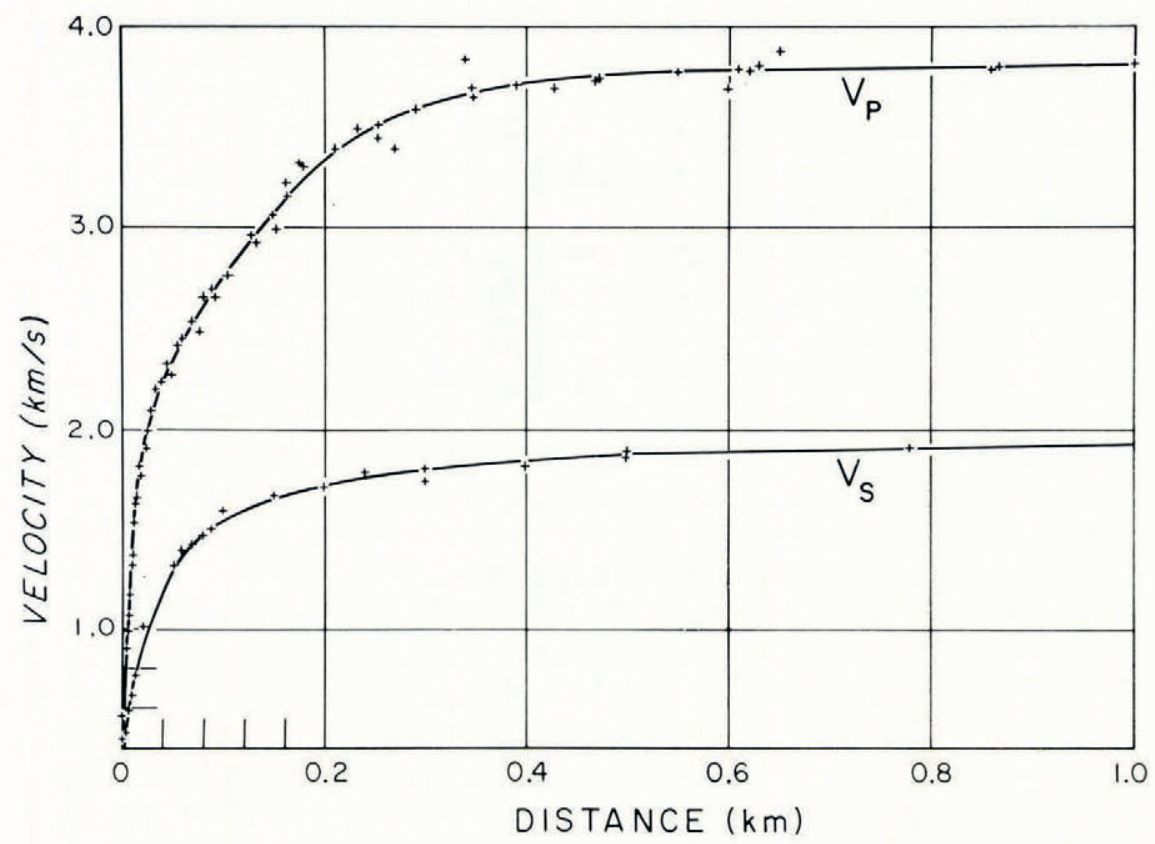

Fig. 2. P-wave and $S$-wave velocity versus distance, new "Byrd"-detail of first kilometer. Velocities are from integration of the travel-time curves.

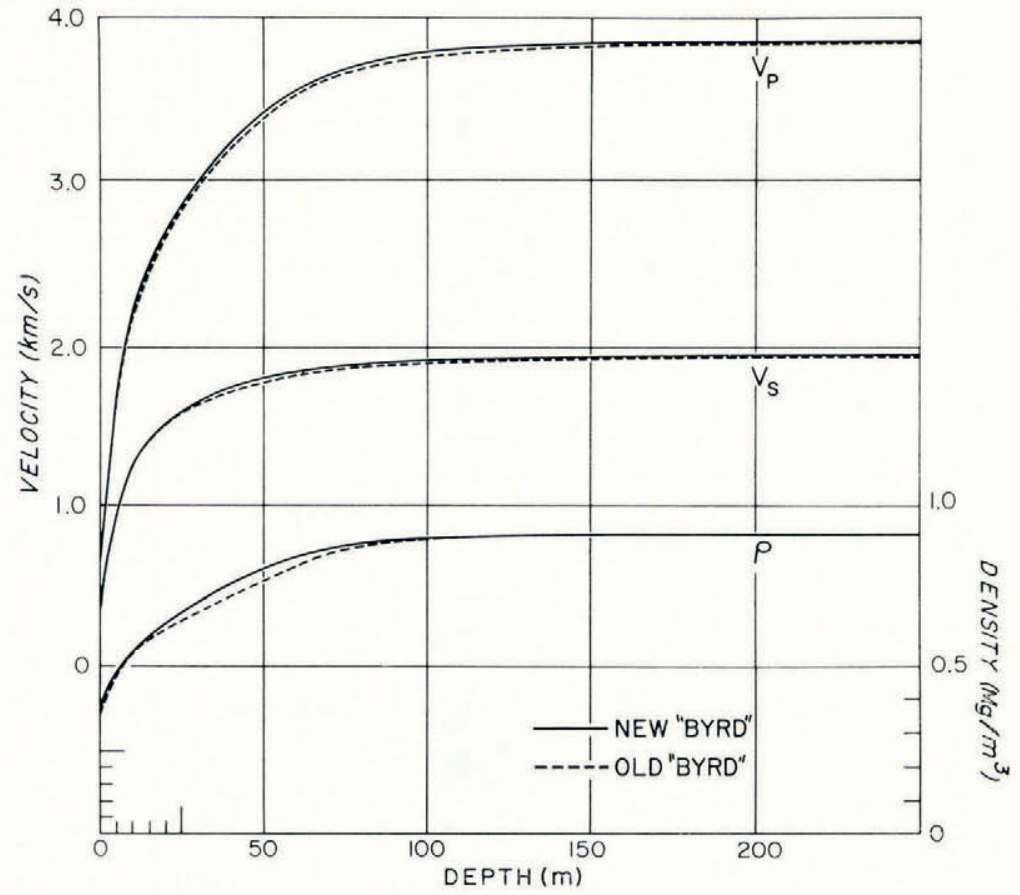

Fig. 3. P-wave and $S$-wave velocities and densities versus depth. 
from old and new "Byrd" stations (Gow, I968; personal communication from A. J. Gow, 1971), in Figure 3. The velocities increase monotonically with depth and no specific features related to the firn structure are obvious.

At depths less than $100 \mathrm{~m}$ the differences in $\rho(z)$ between the two sites are relatively larger than the corresponding differences in $V_{\mathrm{p}}(z)$ and $V_{\mathrm{s}}(z)$; consequently, no velocitydensity relation can apply accurately at both sites. It has previously been found for measurements on the Greenland ice sheet, however, that sections of the $V_{\mathrm{p}}(z)$ curve can be fitted by an exponential function of the form

$$
V_{\mathrm{p}}(z)=a-b \mathrm{e}^{-c z}
$$

where $a, b$ and $c$ are positive constants, and that changes in the constants can be related to changes in the density-depth curve (Brockamp and Pistor, [1968]; Kohnen, unpublished). A similar analysis is therefore applied here.

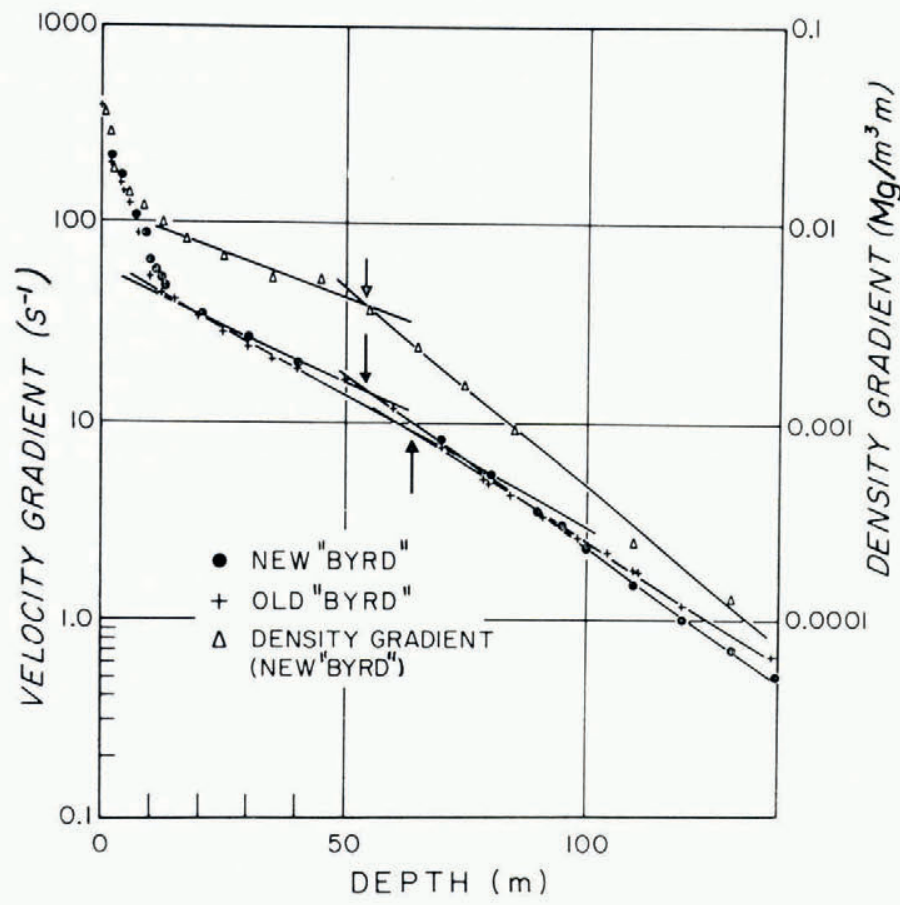

Fig. 4. Velocity gradient $\left(\mathrm{d} V_{\mathrm{p}} / \mathrm{d} z\right)$ and density gradient $(\mathrm{d} \rho / \mathrm{d} z)$ versus depth.

To determine $b$ and $c$, we have for each site plotted the velocity gradient $(\mathrm{d} v / \mathrm{d} z)$ versus depth on semi-log paper (Fig. 4). Each plot falls into three sections, of which the deeper two define very good straight lines. We denote the shallower and deeper section boundaries by $z_{1}$ and $z_{2}$, respectively. Regression lines have been fitted by least squares to the straight-line segments to determine $z_{\mathrm{I}}$ and $z_{2}$, and the constants $b$ and $c$ corresponding to each segment. The corresponding values of $a$ were then determined by comparison with the measured velocities. The appropriate constants for the two sections of $V_{\mathrm{p}}(z)$ are shown in Table II. Note that the parameters differ significantly between the two sites. 
Table II. Parameters of the velocity-Depth function $V_{\mathrm{p}}(z)$. The standard deviations IN $b$ REFER TO DEPTHS $z=30 \mathrm{~m}$ AND $z=100 \mathrm{~m}$ FOR THE UPPER AND LOWER SECTIONS, RESPECTIVELY, i.e. TO DEPTHS LOCATED CENTRALLY WITHIN THE RANGES OF APPLICABILITY OF EQUATION (I), RATHER THAN TO $z=0$

\begin{tabular}{|c|c|c|c|c|c|c|}
\hline Station & $\begin{array}{l}z_{1} \\
\mathrm{~m}\end{array}$ & $\begin{array}{l}z_{2} \\
\mathrm{~m}\end{array}$ & Section & $\underset{\mathrm{km} / \mathrm{s}}{a}$ & $\begin{array}{c}b \\
\mathrm{~km} / \mathrm{s}\end{array}$ & $\stackrel{c}{c}$ \\
\hline New "Byrd" & 14 & $5^{6}$ & $\begin{array}{c}z_{1}<z<z_{2} \\
z>z_{2}\end{array}$ & $\begin{array}{l}4.040 \pm 0.011 \\
3.858 \pm 0.001\end{array}$ & $\begin{array}{l}2.32 \pm 0.04 \\
3.17 \pm 0.05\end{array}$ & $\begin{array}{l}26.7 \pm 0.5 \\
39.9 \pm 0.4\end{array}$ \\
\hline Old "Byrd" & II & 64 & $\begin{array}{c}z_{1}<z<z_{2} \\
z>z_{2}\end{array}$ & $\begin{array}{l}3.782 \pm 0.009 \\
3.844 \pm 0.001\end{array}$ & $\begin{array}{l}2.12 \pm 0.07 \\
2.35 \pm 0.04\end{array}$ & $\begin{array}{l}31.9 \pm 1.0 \\
34.9 \pm 0.4\end{array}$ \\
\hline
\end{tabular}

The section boundaries $z_{1}$ and $z_{2}$ are related to significant depths in the densification process of the firn. Near the surface, densification results mainly from the mechanical rearrangement of the ice grains. At depths between the "critical depth", where $\rho \simeq 0.55 \mathrm{Mg} / \mathrm{m}^{3}$ (Anderson and Benson, I963), and the firn-ice boundary, defined as the point at which the permeability becomes zero, densification occurs by recrystallization. Densification in the ice below occurs simply by the compression of the air bubbles.

At new "Byrd" station the firn-ice boundary depth is put by Gow (1970) at $56 \mathrm{~m}$, in close agreement with depth $z_{2}$. To determine the critical depth, we have plotted $\mathrm{d} \rho / \mathrm{d} z$ versus $z$ (Fig. 4), using densities measured by A. J. Gow (personal communication), to find the abrupt change demonstrated by Anderson and Benson (1963). The change occurs at $14 \mathrm{~m}$, in excellent agreement with depth $z_{1}$.

At old "Byrd" station the agreement between depths determined from $V_{\mathrm{p}}$ and from direct observations (Gow, I965) is again very close: I I $\mathrm{m}$ for $z_{\mathrm{I}}$ versus $\mathrm{ro} \mathrm{m}$ for the critical depth, and $64 \mathrm{~m}$ for $z_{2}$ versus $65 \mathrm{~m}$ for the firn-ice boundary. Thus at both old and new "Byrd" stations the correlation between changes in the parameters of Equation (I) and the changes in the physical process of densification is excellent even though the parameters themselves differ substantially between the two sites. The agreement at the firn-ice boundary is particularly noteworthy in view of the different depths to the boundary at the two sites and the decidedly different velocity-density curves (Fig. 5).

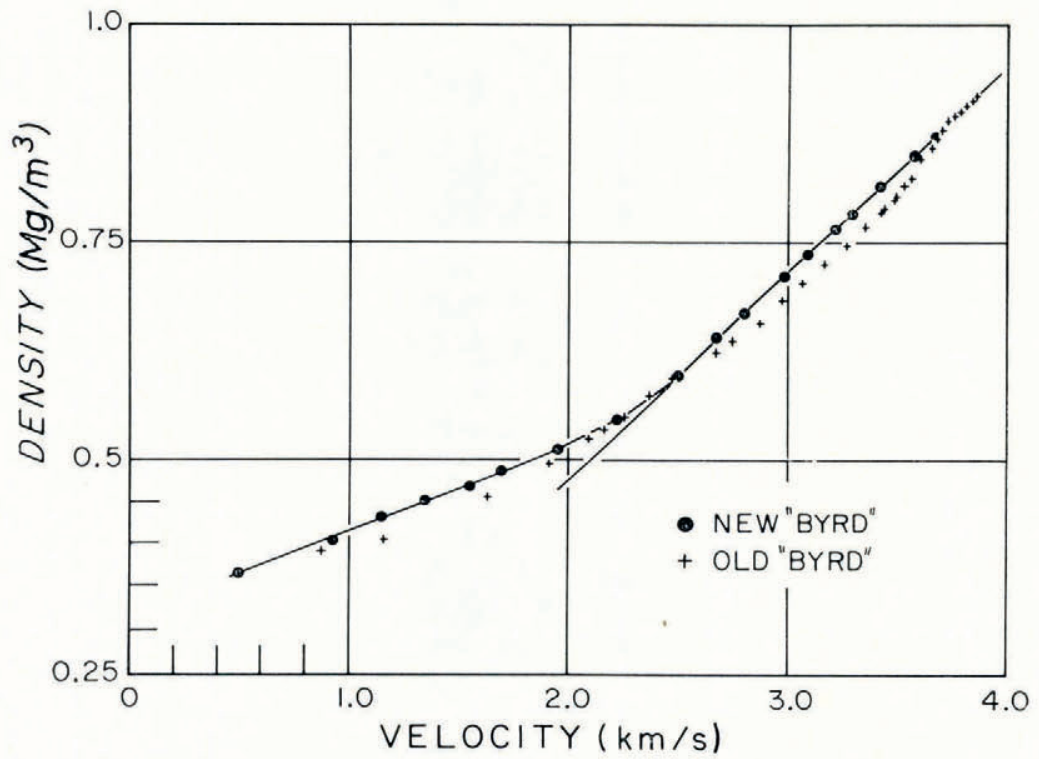

Fig. 5. Densilies versus $P$-wave velocity, linear plot. 
It would be useful to check the correlation between $z_{2}$ and the firn-ice boundary at a site where the boundary is found at a much different depth than at "Byrd" station. Unfortunately, a good set of data is not available for such a site. We can make a rough comparison at South Pole station, however, using the published velocity-depth curve of Weihaupt (1963), and the densities extrapolated by Gow (I968) from measurements to $50 \mathrm{~m}$. We find $z_{2} \approx{ }_{\mathrm{I}} 20 \mathrm{~m}$ compared with a depth to the firn-ice boundary of about I I $\mathrm{m}$, an agreement which is encouraging in view of the uncertainties involved in both determinations.

Density versus velocity. It is also interesting to compare the velocities directly with the density measurements (Fig. 5). At the new "Byrd" site a very close linear relationship between $\rho$ and $V_{\mathrm{p}}$ is found for $\rho>0.55 \mathrm{Mg} / \mathrm{m}^{3}$, yielding the regression line equation

$$
\rho=(0.239 \pm 0.002) V_{\mathrm{p}}-0.002 \pm 0.009
$$

where $V_{\mathrm{p}}$ is in $\mathrm{km} / \mathrm{s}$. In contrast, the density-velocity curve at the old "Byrd" site is decidedly non-linear.

Other investigations have yielded no single density-velocity relationship which applies generally to dry firn-ice. Robin (1958) found a good fit to the equation

$$
\rho=0.22 \mathrm{I} V_{\mathbf{p}}+0.059
$$

for both ultrasonic laboratory measurements on Alpine firn-ice and field measurements at Maudheim; Equations (2) and (3) agree fairly well. On the other hand, Bennett (unpublished), from laboratory measurements of ultrasonic velocities in several cores from Greenland and Antarctica found the substantially different linear relationship

$$
\rho=0.308 V_{\mathrm{p}}-0.269 \text {, }
$$

and most seismic refraction measurements do not lead to a linear relationship at all (Röthlisberger, 1972). Consequently, it seems likely that a density-depth curve appropriate to an individual site can better be obtained by using velocity-gradient changes determined locally combined with densification theory than by using a universal density-velocity function. A study of this possibility is in progress.

For $\rho>0.55 \mathrm{Mg} / \mathrm{m}^{3}$ the following logarithmic relationships fit well (Fig. 6):

New "Byrd": $\ln \rho=(0.236 \pm 0.006) V_{\text {p }}-$ I. I $16 \pm 0.008$

Old "Byrd": $\ln \rho=(0.260 \pm 0.007) V_{\mathrm{p}}-\mathrm{I} .207 \pm 0.0 \mathrm{II}$

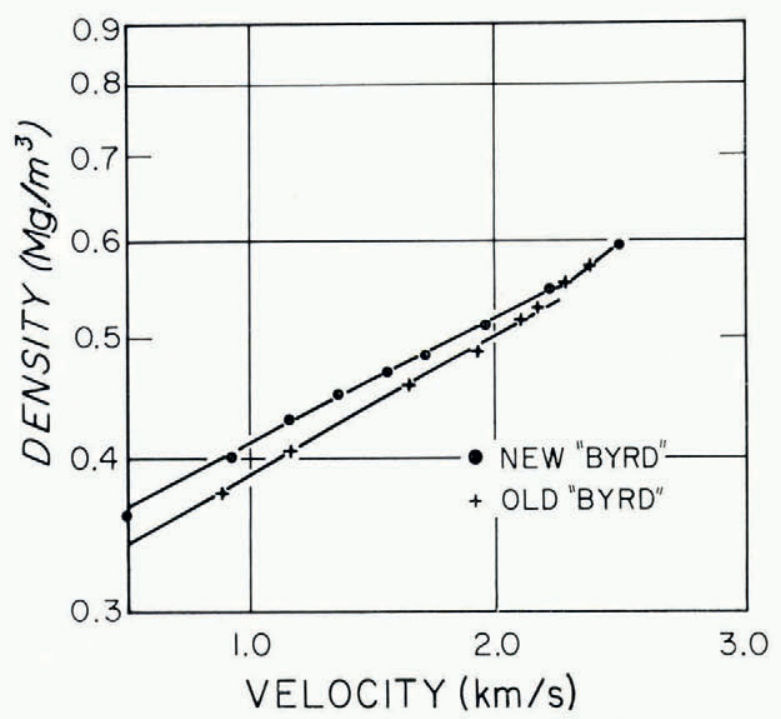

Fig. 6. Densities less than $0.5 \mathrm{Mg} / \mathrm{m}^{3}$ versus $P$-wave velocities, semi-log plot. 
showing again the significant difference between the two sites. We do not yet know how well a logarithmic function may apply to other locations, but no fixed relationship of any form can be applied at depths less than Io $\mathrm{m}$ without taking into account the effects of the annual temperature cycle, which are not well known.

Elastic parameters. From $V_{\mathrm{p}}$ and $V_{\mathrm{s}}$ we can calculate Poisson's ratio $\sigma$ as a function of depth (Fig. 7). The values at the maximum depth of penetration (new "Byrd": $\sigma=0.329$; old "Byrd": $\sigma=0.330$ ) are in agreement with many other investigations. The main features of the $\sigma(z)$ curves, which are similar at the two sites, are undoubtedly related to $z_{1}$ and $z_{2}$ : a minimum in $\sigma$ between 10 and $15 \mathrm{~m}$, a rapid increase in $\sigma$ below to about $60 \mathrm{~m}$, and a nearly constant value at greater depths. Detailed variations in $\sigma$, such as the lower minimum value at old "Byrd", as well as those in the uppermost few meters must be regarded with suspicion, since small errors in the velocities cause relatively large errors in $\sigma$.

The dynamic elastic moduli-Young's modulus and the shear modulus - are also plotted in Figure 7 .

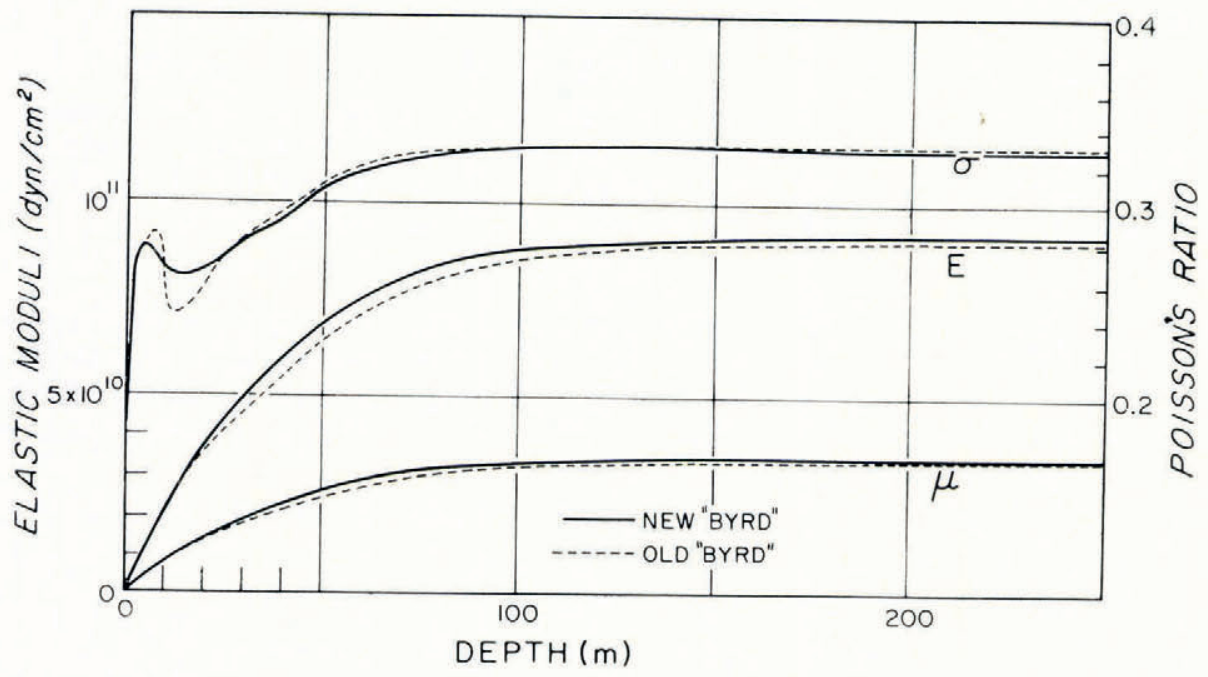

Fig. 7. Young's modulus, $E$, the shear modulus, $\mu$, and Poisson's ratio, $\sigma$, versus depth.

\section{REFLEGTION MEASUREMENTS}

Good wide-angle reflections were recorded on the new "Byrd" profiles (old "Byrd" reflection results are published elsewhere (Bentley, 197I)). Plotting (travel time) ${ }^{2}$ as a function of (distance) ${ }^{2}$ for profile I (the common-reflection-point profile) on which the travel times are unaffected by subglacial topographic variations, we notice very slight but systematic deviations from the straight line to be expected for an isotropic ice sheet (Fig. 8). These deviations result from anisotropy in the ice sheet. To examine them, we follow the procedure of Bentley (197I, q.v. for more details). Calculate the mean velocity through the ice, $\bar{\nabla}_{\mathrm{p}}$, for each shot from the equation

$$
\bar{V}_{\mathrm{p}^{2}}=\frac{X^{2}+\left(V_{\mathrm{II}}\right)_{0}{ }^{2}\left(T_{\mathrm{p}}\right)_{0}{ }^{2}}{T_{\mathrm{p}^{2}}} .
$$

$X$ is the mean shot-detector distance, $\left(T_{\mathrm{p}}\right)_{0}$ and $T_{\mathrm{p}}$ are the observed vertical and wide-angle reflection times respectively, and $\left(V_{\mathrm{II}}\right)_{0}$ is a value for the vertical velocity chosen to be consistent with the anisotropic model being tested (Bentley, r97I). Then plot $\bar{V}_{\mathrm{p}}$ as a function of the angle of incidence $i_{\mathrm{p}}$, given by

$$
\cos i_{\mathrm{p}}=\left(T_{\mathrm{p}}\right)_{\mathrm{o}} / \mathcal{T}_{\mathrm{p}}
$$




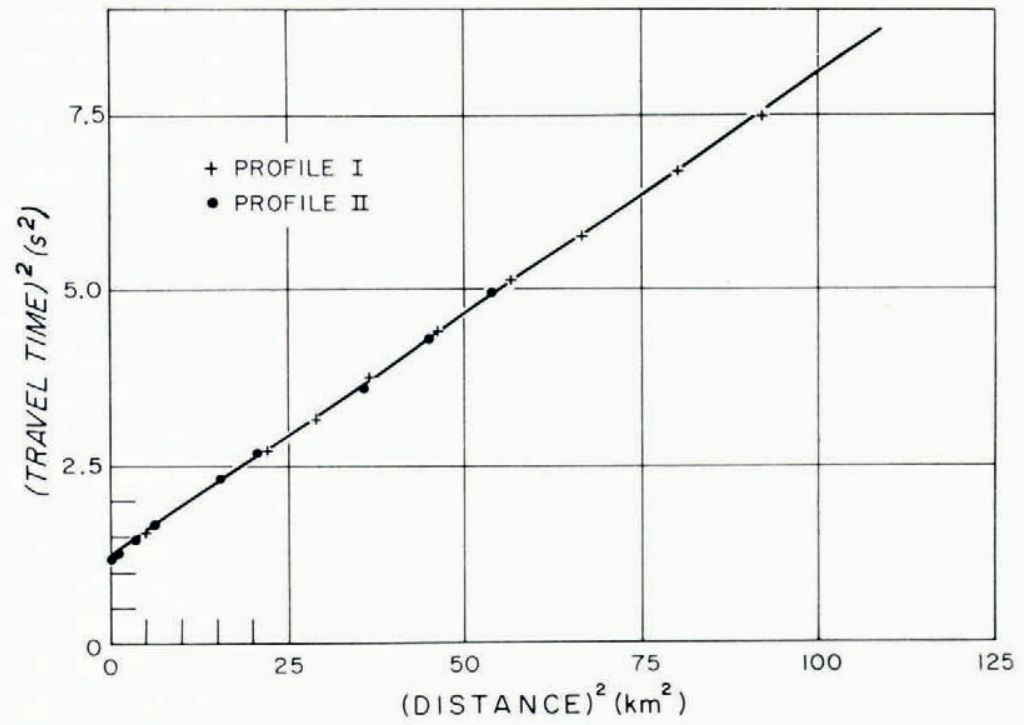

Fig. 8. $T^{2}-X^{2}$ plot of wide-angle reflections.

The effects of the near-surface velocity gradient and anisotropic velocity variations are negligible in determining $i_{\mathrm{p}}$. Velocities $V_{\mathrm{II}}$ corresponding to a particular anisotropic model are obtained as a function of $i_{\mathrm{p}}$ from

$$
V_{11}=q_{\mathrm{p}} \Delta V_{\mathrm{II}}+\left(V_{\mathrm{p}}\right)_{\mathrm{I}}-\mathrm{IO} \mathrm{m} / \mathrm{s},
$$

where $\left(V_{\mathrm{p}}\right)_{\mathrm{I}}$ is the velocity in isotropic ice; $\Delta V_{\mathrm{II}}$ the difference between $\left(V_{\mathrm{p}}\right)_{\mathrm{I}}$ and the velocity of a wave propagating in a single ice crystal at that angle with the $c$-axis which corresponds to the given $i_{\mathrm{p}}$ and the assumed preferred $c$-axis orientation in the ice sheet, $-10 \mathrm{~m} / \mathrm{s}$ is a temperature correction corresponding to the downward temperature increase, and $q_{\mathrm{p}}$ is the proportion of the total ice thickness assumed to be anisotropic.

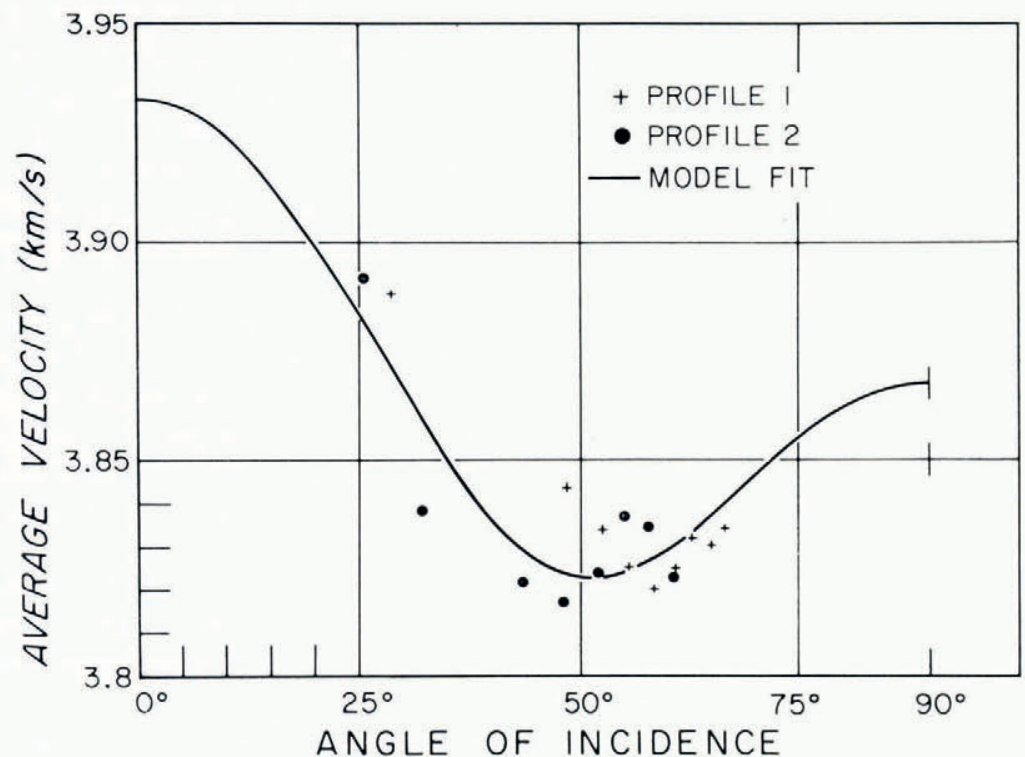

Fig. 9. Average velocity $\bar{\nabla}_{\mathrm{p}}$ versus angle of incidence $i_{\mathrm{p}}$. 
The resulting plot is shown in Figure 9. The solid curve is obtained from Equation (4), assuming $q_{\mathrm{p}}=40 \%$ and a vertical preferred orientation, as found in the deep drill hole at new "Byrd" station (Gow, I968). The mean vertical velocity of $3.93 \mathrm{~km} / \mathrm{s}$ is in satisfactory agreement with that $(3.90 \mathrm{~km} / \mathrm{s})$ from model fitting at old "Byrd" station (Bentley, I97I) and with that $(3.915 \mathrm{~km} / \mathrm{s})$ estimated from sonic logging to a depth of I $500 \mathrm{~m}$ in the deep drill hole (Bentley, 1972), extrapolating to the base of the ice on the basis of measured ice fabrics.

Also shown in Figure 9 are $V_{\mathrm{II}}$ values calculated from profile 2. The agreement is good, but the profile carries less weight than the common-reflection-point profile because details of the bedrock topography along profile 2 are lacking. One vertical reflection shot $5 \mathrm{~km}$ from the recording point for profile 2 indicated essentially no change in ice thickness; apparently topographic variations along the line are also small. Bedrock elevation changes along profile 3 were greater and the results have been omitted, although general agreement was again found.

It is worth pointing out that the deviations from a straight-line fit to the plot in Figure 8 could very easily have been overlooked, had they not been expected. The mean velocity through the ice calculated from the regression line in Figure 8 on the assumption of isotropy agrees very closely with the maximum velocity from refraction measurements, after proper allowance is made for near-surface low velocities and the effect of higher temperatures at depth. The agreement, however, is accidental.

\section{Conclusions}

The Antarctic ice sheet is transversely isotropic at a depth of $200-300 \mathrm{~m}$ as shown by the agreement within $0.1 \%$ between values of $\left(V_{\mathrm{p}}\right)_{\max }$ measured in different directions. From fabric studies, however, the ice-crystal $c$-axes are known to have a definite vertical preferred orientation in this depth range (personal communication from A. J. Gow, 1971). For example, at new "Byrd" some two-thirds of the $c$-axes lie within $45^{\circ}$ of the vertical, i.e. in a conical region which subtends only $30 \%$ of the total spherical surface. For such a conical distribution of axcs, the velocity of vertically polarized shear waves is several times more sensitive to distribution changes than is the $P$-wave velocity (Bennett, unpublished). The velocity differences between old and new "Byrd" station seismic shooting sites are thus consistent with the hypothesis that there is a slightly more concentrated fabric pattern (averaged horizontally over several kilometers) at the latter site which results in a $0.2 \%$ difference in $\left(V_{\mathrm{p}}\right)_{\max }$ and a $0.8 \%$ difference in $\left(V_{\mathrm{s}}\right)_{\text {max }}$. A more concentrated pattern at new "Byrd" is in turn consistent with the lower accumulation rate, and correspondingly greater age at a given depth. Thus careful measurements of "maximum" velocities are potentially useful in studying regional variations in ice fabrics.

The investigations at "Byrd" station are encouraging in terms of the feasibility of determining density-depth curves in dry firn-ice from seismic velocities alone. Although a single density-velocity relationship applicable to all sites does not exist, our results suggest that the "critical depth" of densification (depth of change from re-orientation to recrystallization of grains) and the depth of the firn-ice (vanishing permeability) boundary can be determined by examination of the $P$-wave velocity gradient. Since the densities at these two depths are known fairly closely, it should be possible to interpolate and extrapolate a density-depth curve using densification theory (Bader, r962; Anderson and Benson, 1963) determining in the process the mean annual snow accumulation. In carrying out more detailed examination of this possibility, allowance for the effect of anisotropy in determining $\mathrm{d} v / \mathrm{d} z$ versus depth, which we have ignored in this paper, should be made.

The dependence of the mean $P$-wave velocity through the ice upon angle of incidence, found near old "Byrd" station (Bentley, I97I), is confirmed by the present measurements, 
which are in turn consistent with sonic logging in the deep drill hole and with calculations based on observed fabrics. The mean vertical velocity of $3.90-3.93 \mathrm{~km} / \mathrm{s}$ is $2 \%$ higher than those which have commonly been used for calculating ice thicknesses from seismic reflection surveys. The high velocity cannot automatically be applied elsewhere, however, since seismic evidence indicates strikingly different anisotropic patterns in the ice in different regions (Bentley, 1971).

\section{Acknowledgements}

The authors wish to express their appreciation for invaluable assistance with the field work to J. D. Robertson and B. Kososki in $1970-7 \mathrm{I}, \mathrm{L}$. A. LeSchack and G. R. Toney in 1958, and N. A. Ostenso in 1957. The current research was supported by the National Science Foundation under grants GV-27044 and GA-I 706.

MS. received II October 197 I

\section{REFERENCES}

Anderson, D. L., and Benson, C. S. 1963. The densification and diagenesis of snow. (In Kingery, W. D., ed. Ice and snow; properties, processes, and applications: proceedings of a conference held at the Massachusetts Institute of Technology, February $12-16$, 1962 . Cambridge, Mass., The M.I.T. Press, p. 391-411.)

Bader, H. 1962. Theory of densification of dry snow on high polar glaciers. U.S. Cold Regions Research and Engineering Laboratory. Research Report 108.

Bennett, H. F. Unpublished. An investigation into velocity anisotropy through measurements of ultrasonic wave velocities in snow and ice cores from Greenland and Antarctica. [Ph.D. thesis, University of Wisconsin, I968.]

Bentley, C. R. 1971. Seismic anisotropy in the west Antarctic ice sheet. (In Crary, A. P., ed. Antarctic snow and ice studies II. Washington, D.C., American Geophysical Union, p. I31-77. (Antarctic Research Series, Vol. 16.))

Bentley, C. R. 1972. Seismic-wave velocities in anisotropic ice: a comparison of measured and calculated values in and around the deep drill hole at Byrd station, Antarctica. Journal of Geophysical Research, Vol. 77, No. 23, p. 4406-20.

Brockamp, B., and Pistor, P. [1 968.] Ein Beitrag zur seismischen Erforschung der Struktur des grönlandischen Inlandeises. Polarforschung, Bd. 6, Jahrg. 37, Ht. I-2, 1967, p. $133-46$.

Gow, A. J. 1965. The ice sheet. (In Hatherton, T., ed. Antarctica. London, Methuen, p. 221-58.)

Gow, A. J. 1968. Deep core studies of the accumulation and densification of snow at Byrd station and Little America V, Antarctica. U.S. Cold Regions Research and Engineering Laboratory. Research Report i 97.

Gow, A. J. 1970. Preliminary results of studies of ice cores from the $2164 \mathrm{~m}$ deep drill hole, Byrd station, Antarctica. [Union Géodésique et Géophysique Internationale. Association Internationale d'Hydrologie Scientifique.] [International Council of Scientific Unions. Scientific Committee on Antarctic Research. International Association of Scientific Hydrology. Commission of Snow and Ice.] International Symposium on Antarctic Glaciological Exploration (ISAGE), Hanover, New Hampshire, U.S.A., 3-7 September 1968, p. 78-90.

Gow, A. J., and Rowland, R. 1965. On the relationship of snow accumulation to surface topography at "Byrd station", Antarctica. Fournal of Glaciology, Vol. 5, No. 42, p. 843-47.

Kohnen, H. Unpublished. Über den Aufbau des grönlandischen Inlandeises nach refraktionsseismischen Messungen. [Ph.D. thesis, Münster, Westfälische Wilhelms-Universität, 1969.]

Robin, G. de Q. 1958. Glaciology. III. Seismic shooting and related investigations. Norwegian-British-Swedish Antarctic Expedition, 1949-52. Scientific Results, Vol. 5.

Röthlisberger, H. 1972. Seismic exploration in cold regions. U.S. Cold Regions Research and Engineering Laboratory. Cold regions science and engineering. Hanover, N.H., Pt. II, Sect. A2a.

Weihaupt, J. G. 1963. Seismic and gravity studies at the South Pole. Geophysics, Vol. 28, No. 4, p. 582-92. 